\title{
Comparison of Restoration of Protein Contents of Preserved Rohu (Labio rohita), Treated under Different Cooking Conditions
}

\author{
Uttiya Jana ${ }^{1}$, Sarmistha Chakrabarti ${ }^{2}$ \\ Department of Home Science (Food \& Nutrition), University of Calcutta, Kolkata 700 027, India
}

\begin{abstract}
Fish are rich sources of protein commonly consumed as an alternative source of protein due to higher cost of other animal proteins. This study was based on the comparison of protein contents of rohu preserved with the combination of salt and turmeric and without preservative for 24 hours, 48 hours, 14 days and 15 days. This preserved fish was subjected to conventional cooking methods like open pan dry roasting, boiling, shallow frying and deep frying. The protein contents of cooked fish were significantly lower than those in the raw condition. The nutrient contents change due to cooking. Loss of nutrients mainly occurs in boiling whereas it is better restored in deep fat frying method. The study significantly showed that the protein loss occurs due to preservation but this loss can be reduced by using the combination of salt and turmeric.
\end{abstract}

Keywords: Rohu, protein, cooking methods, preservatives, deep fat frying

\section{Introduction}

Fish is consumed mainly as a rich source of protein. But the nutrient contents change when it is preserved and cooked as shown in some studies previously carried out. In one study, three commonly available species of marine fish in Nigeria were subjected to boiling, frying and roasting and the effects of these cooking methods on the fish were observed. The results showed reduced protein content for all the fish types (1). In yet another research, amino acid and proximate compositions were determined in six commonly consumed raw and cooked marine fish in Turkey. The changes in amino acid and proximate contents were found to be significant for all cooking methods in all fish species ${ }^{(2)}$. Another research showed that cooking methods were also applied for vegetable samples which could also be a reference for this present study. Three cooking methods, namely boiling, steaming and stir-frying were used to evaluate the effect on nutrient components of bamboo shoots, resulting in decreased contents of protein, soluble sugar and ash. Results indicated an appreciable loss in the total free amino acids in boiling method. All procedures were carried out for 10 minutes ${ }^{(3)}$. The effects of five domestic cooking methods, including steaming, microwaving, boiling, stir-frying and stir-frying followed by boiling on the nutrients and health-promoting compounds of broccoli were investigated. The results showed that all cooking treatments, except steaming, caused significant losses of total soluble proteins and soluble sugars ${ }^{(4)}$. The effects of different cooking methods (boiling, baking, frying and grilling) on proximate and mineral composition of snakehead fish were investigated. The changes in the amount of protein and fat were found to be significantly higher in frying and grilling fish ${ }^{(5)}$. Another study was designed to observe the performance of turmeric and salt on tengra (Mystus vittatus) for several days, stored with preservatives of $2 \%$ of the sample weight, resulting in nutrient restoration. ${ }^{(6)}$ The present study is significant due to the comparison of protein contents of rohu after being preserved for several days and then subjected to cooking. Preservation can cause loss of protein; however, the amount of protein that can be restored using a combination of salt and turmeric for 15 days, is investigated in this study.

- This study aims to estimate the protein contents of rohu in both raw and cooked conditions after being preserved for 24 hours, 48 hours, 14 days and 15 days with and without preservative.

- This study also aims at finding comparison of protein contents of preserved and cooked fish with and without preservative.

- To find the deterioration level of preserved fish in the perspective of protein content is the most important concern of this study.

\section{Materials and Methods}

\section{1) Sample Preparation and Cooking}

Rohu (Labio rohita), with a length of $25-30 \mathrm{~cm}$ and weight of $1 \mathrm{~kg}$ was obtained from the local fish market in Kolkata. It was kept in a plastic container, transported to the laboratory and washed with tap water several times to remove adhering blood and excessive mucous. Subsequently the fish sample was filleted into three sections and each section was divided into five groups. In the first section one group was left uncooked while the other four were boiled, dry roasted in open pan, shallow fried and deep fried. Boiling was performed at $99-101^{\circ} \mathrm{C}$ (water temperature) for 10 minutes. Open pan dry roasting of fillets was performed in a pan at $180^{\circ} \mathrm{C}$ for 10 minutes. The frying of fillets was performed in a domestic frying pan of $2 \mathrm{~L}$ capacity at a temperature of approximately $180{ }^{\circ} \mathrm{C}$ for 10 minutes. Mustard oil was used as the medium for frying. In case of shallow frying, $10 \mathrm{ml}$ oil was used and for deep frying 20 $\mathrm{ml}$. The other two sections were allowed to preserve up to15 days. Among these two sections, one was preserved in the refrigerator at $-20^{\circ} \mathrm{C}$ without preservative and the other section was preserved with the combination of salt and turmeric. The amount of combination of salt and turmeric was used as $2 \%$ of the weight of the fish sample preserved in 1:1 ratio. The raw, fresh and preserved samples were then 


\section{International Journal of Science and Research (IJSR) \\ ISSN (Online): 2319-7064 \\ Index Copernicus Value (2013): 6.14 | Impact Factor (2014): 5.611}

subjected to analysis post cooking on the day of preservation of $1^{\text {st }}, 2^{\text {nd }}, 14^{\text {th }}$ and $15^{\text {th }}$.

\section{2) Proximate Composition Analysis}

Proximate composition analyses for homogenized samples of fresh and preserved fish fillets, both raw and cooked, were done in triplicate for protein contents. The crude protein content was determined by the Lowry method ${ }^{(7)}$.

\section{Estimation of Protein by Lowry Method ${ }^{(7)}$}

$200 \mathrm{mg}$ of sample was taken and $20 \mathrm{ml}$ of buffer, containing sodium dihydrogen phosphate and disodium hydrogen phosphate, was added and homogenized finely. Then it was kept overnight. After that it was cold centrifuged at 5000 RPM for 20 minutes. The supernatant was collected and 1 $\mathrm{ml}$ of it was used for analysis. Then $5 \mathrm{ml}$ of Lowry reagent was added to the supernatant and allowed to incubate for 10 minutes. After that $0.5 \mathrm{ml}$ of Folinciocaltue reagent was added and incubated for 30 minutes until a dark blue colour appeared. The reading was taken at $660 \mathrm{~nm}$ by spectrophotometer (Perkin Elmer Lambda 25).

\section{3) Statistical analysis}

The effect of different cooking methods on protein content of fresh and preserved rohu was analyzed using Mean and Standard Deviations. Paired sample $\mathrm{t}$ - test was done for comparing the protein contents between preserved fish with and without preservative. Differences were considered to be significant when $\mathrm{p}$ value is $<0.05$. Data were analyzed by using SPSS package (Version 17).

\section{Result}

Table 1: Protein content of fresh rohu

\begin{tabular}{|c|c|c|c|c|}
\hline Raw & Boiling & Dry roasting & $\begin{array}{c}\text { Shallow } \\
\text { frying }\end{array}$ & Deep frying \\
\hline $17.50 \pm 0.50$ & $3.03 \pm 0.23$ & $5.70 \pm 0.10$ & $5.03 \pm 0.15$ & $7.33 \pm 0.15$ \\
\hline
\end{tabular}

Table 2: Protein content of preserved rohu without preservative

\begin{tabular}{|c|c|c|c|c|c|}
\hline Duration & Raw & Boiling & $\begin{array}{c}\text { Dry } \\
\text { roasting }\end{array}$ & $\begin{array}{c}\text { Shallow } \\
\text { frying }\end{array}$ & $\begin{array}{c}\text { Deep } \\
\text { frying }\end{array}$ \\
\hline 24 hours & $16.50 \pm 0.50$ & $4.40 \pm 0.00$ & $5.60 \pm 0.20$ & $4.46 \pm 0.05$ & $7.40 \pm 0.17$ \\
\hline 48 hours & $13.06 \pm 0.51$ & $3.40 \pm 0.10$ & $5.60 \pm 0.20$ & $4.06 \pm 0.11$ & $5.10 \pm 0.10$ \\
\hline 14 days & $7.23 \pm 0.25$ & $5.0 \pm 0.10$ & $5.66 \pm 0.28$ & $5.83 \pm 0.05$ & $8.76 \pm 0.05$ \\
\hline 15 days & $6.26 \pm 0.05$ & $4.10 \pm 0.10$ & $5.26 \pm 0.25$ & $5.76 \pm 0.05$ & $7.53 \pm 0.05$ \\
\hline
\end{tabular}

Table 3: Protein content of preserved rohu with the combination of salt and turmeric

\begin{tabular}{|c|c|c|c|c|c|}
\hline Duration & Raw & Boiling & Dry roasting & $\begin{array}{c}\text { Shallow } \\
\text { frying }\end{array}$ & $\begin{array}{c}\text { Deep } \\
\text { frying }\end{array}$ \\
\hline
\end{tabular}

\begin{tabular}{|l|l|l|l|l|l|}
\hline 24 hours & $16.83 \pm 0.15$ & $6.20 \pm 0.20$ & $13.10 \pm 0.17$ & $13.26 \pm 0.25$ & $15.86 \pm 0.1$ \\
\hline
\end{tabular} \begin{tabular}{|l|l|l|l|l|}
\hline 48 hours $15.60 \pm 0.177 .03 \pm 0.57$ & $9.93 \pm 0.11$ & $5.80 \pm 0.00$ & $8.8 \pm 0.10$ \\
\hline
\end{tabular} \begin{tabular}{|l|l|l|l|l|l|}
\hline 14 days & $14.06 \pm 0.05$ & $5.26 \pm 0.05$ & $8.6 \pm 0.10$ & $6.8 \pm 0.20$ & $11.8 \pm 0.05$ \\
\hline
\end{tabular} \begin{tabular}{|l|l|l|l|l|l|l|}
15 days & $12.03 \pm 0.05$ & $4.93 \pm 0.11$ & $6.10 \pm 0.10$ & $6.26 \pm 0.17$ & $8.6 \pm 0.05$ \\
\hline
\end{tabular}

Table 4: Comparison of protein content of preserved rohu with and without preservative

\begin{tabular}{|c|c|c|c|c|c|}
\hline Duration & Raw & Boiling & $\begin{array}{c}\text { Dry } \\
\text { roasting }\end{array}$ & $\begin{array}{c}\text { Shallow } \\
\text { frying }\end{array}$ & $\begin{array}{c}\text { Deep } \\
\text { frying }\end{array}$ \\
\hline 24 hours & $0.242(\mathrm{~S})$ & $0.004(\mathrm{~S})$ & $0.000(\mathrm{~S})$ & $0.000(\mathrm{~S})$ & $0.00(\mathrm{~S})$ \\
\hline 48 hours & $0.013(\mathrm{~S})$ & $0.000(\mathrm{~S})$ & $0.000(\mathrm{~S})$ & $0.001(\mathrm{~S})$ & $0.000(\mathrm{~S})$ \\
\hline 14 days & $0.038(\mathrm{~S})$ & $0.057(\mathrm{NS})$ & $0.003(\mathrm{~S})$ & $0.015(\mathrm{~S})$ & $0.000(\mathrm{~S})$ \\
\hline 15 days & $0.000(\mathrm{~S})$ & $0.002(\mathrm{~S})$ & $0.011(\mathrm{~S})$ & $0.023(\mathrm{~S})$ & $0.003(\mathrm{~S})$ \\
\hline
\end{tabular}

$(\mathrm{P}$ value $=<0.05=$ significantly different $)(\mathrm{S}=$ significant NS $=$ Non significant

Table 5: Percentage of loss of protein in cooked rohu preserved without preservative

\begin{tabular}{|l|c|c|c|c|}
\hline Duration & Boiling & Dry roasting & Shallow frying & Deep frying \\
\hline 24 hours & 73.3 & 66.06 & 72.96 & 55.15 \\
\hline 48 hours & 74.01 & 57.12 & 68.86 & 60.94 \\
\hline 14 days & 30.84 & 21.71 & 19.36 & -21.16 \\
\hline 15 days & 34.50 & 15.97 & 7.98 & -20.28 \\
\hline
\end{tabular}

Table 6: Percentage of loss of protein in cooked rohu preserved with salt and turmeric

\begin{tabular}{|l|l|l|l|l|l|}
\hline Duration & Raw & Boiling & $\begin{array}{c}\text { Dry } \\
\text { Roasting }\end{array}$ & $\begin{array}{l}\text { Shallow } \\
\text { Frying }\end{array}$ & Deep Frying \\
\hline 24 hours & 63.16 & 22.16 & 21.21 & 5.76 & 63.16 \\
\hline 48 hours & 54.93 & 36.34 & 62.82 & 43.58 & 54.93 \\
\hline 14 days & 62.58 & 38.83 & 51.63 & 16.07 & 62.58 \\
\hline 15 days & 59.01 & 49.29 & 48.46 & 28.01 & 59.01 \\
\hline
\end{tabular}

Table 7: Percentage of loss of protein in preserved rohu without preservative in comparison to fresh

\begin{tabular}{|l|c|c|c|c|c|}
\hline Duration & Raw & Boiling & $\begin{array}{c}\text { Dry } \\
\text { Roasting }\end{array}$ & $\begin{array}{c}\text { Shallow } \\
\text { Frying }\end{array}$ & Deep Frying \\
\hline 24 hours & 5.71 & -45.21 & 1.75 & 11.33 & -1.36 \\
\hline 48 hours & 25.37 & -12.21 & 1.75 & 19.28 & 30.13 \\
\hline 14 days & 58.68 & -65.01 & 0.70 & -15.90 & -20.0 \\
\hline 15 days & 64.22 & -35.31 & 7.71 & -14.51 & -3.15 \\
\hline
\end{tabular}

Table 8: Percentage of loss of protein in preserved rohu with preservative in comparison to fresh

\begin{tabular}{|c|c|c|c|c|c|}
\hline Duration & Raw & Boiling & $\begin{array}{c}\text { Dry } \\
\text { Roasting }\end{array}$ & $\begin{array}{c}\text { Shallow } \\
\text { Frying }\end{array}$ & Deep Frying \\
\hline 24 hours & 3.82 & -104.62 & -129.82 & -163.61 & -117.26 \\
\hline 48 hours & 10.85 & -132.01 & -74.21 & -15.30 & -20.54 \\
\hline 14 days & 19.65 & -73.59 & -50.87 & -35.18 & -61.6 \\
\hline 15 days & 31.25 & -62.70 & -7.01 & -24.45 & -18.63 \\
\hline
\end{tabular}




\section{International Journal of Science and Research (IJSR) \\ ISSN (Online): 2319-7064}

Index Copernicus Value (2013): 6.14 | Impact Factor (2014): 5.611

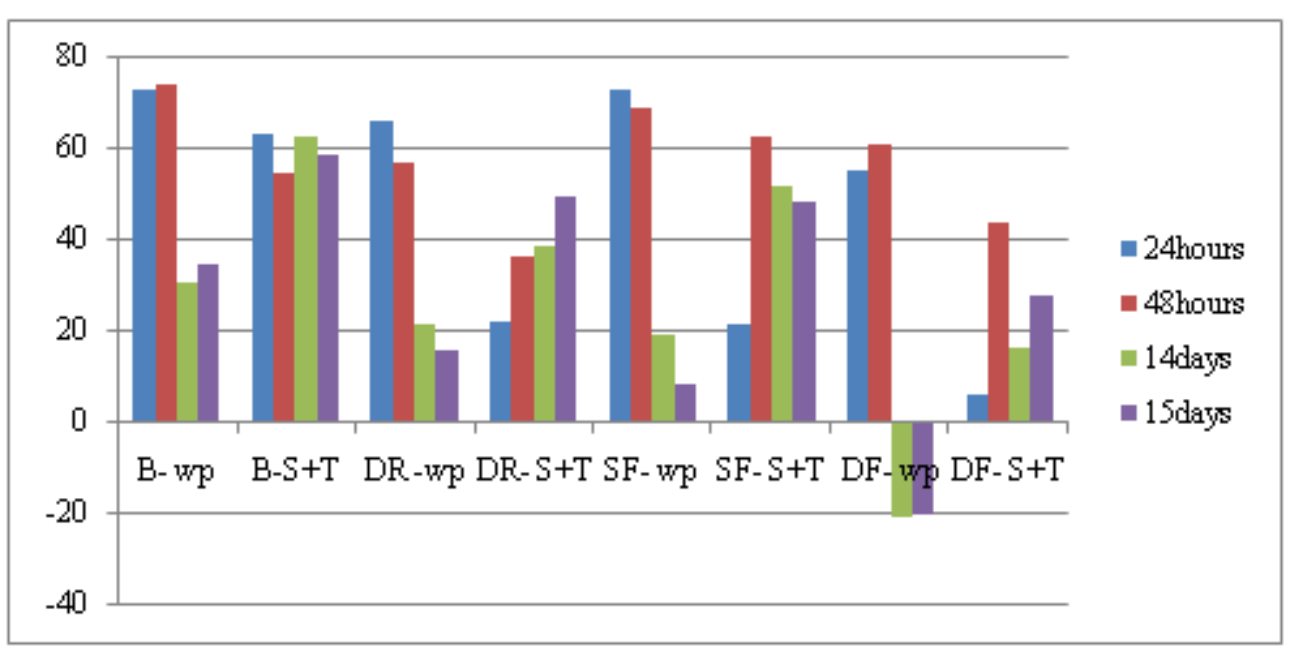

Figure (a): Percentage loss of preserved rohu in different cooking methods

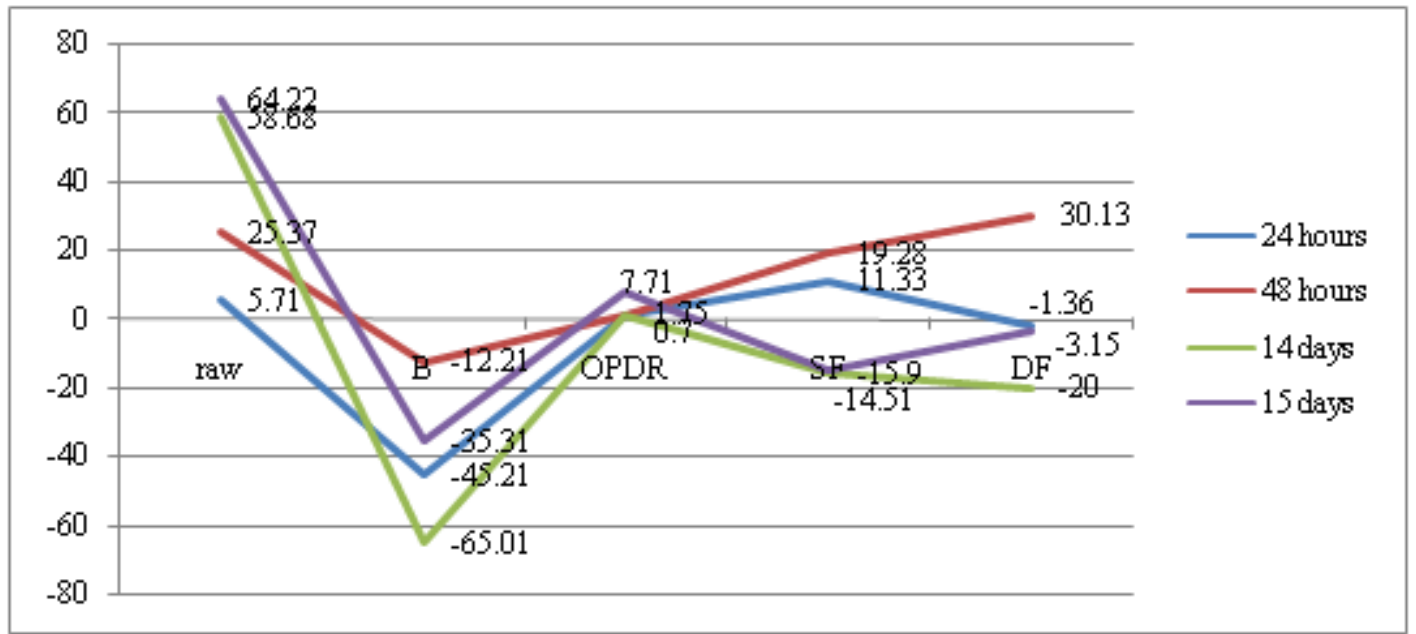

Figure (b): Percentage loss of preserved rohu without preservative in different cooking methods

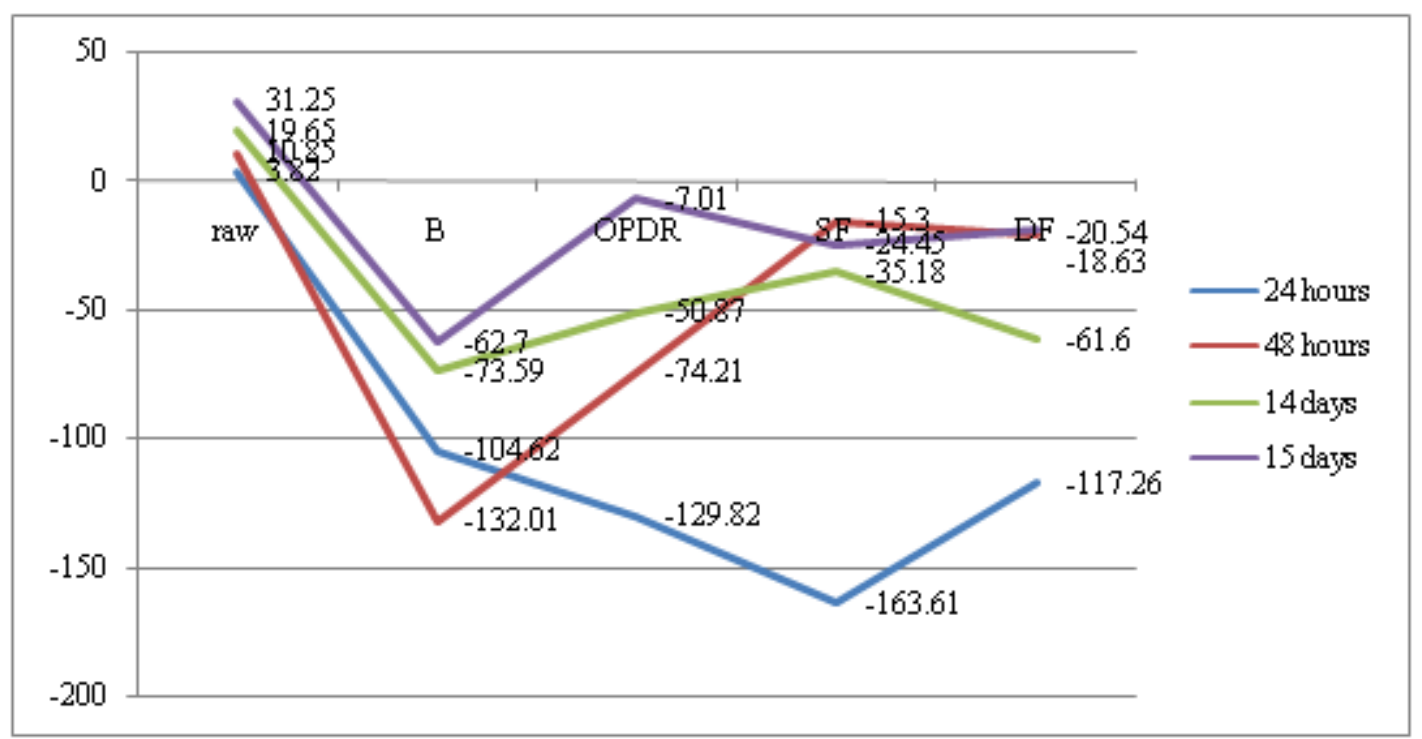

Figure (c): Percentage loss of preserved rohu with salt and turmeric in different cooking methods

\section{Discussion}

Table 1 showed the protein content of rohu after subjecting it to different cooking methods. The raw and cooked values were displayed here. The protein content was reduced due to application of different cooking methods. The highest loss occurs in boiling and it was found to be restored in deep frying method.

Table 2 showed the protein contents of preserved rohu without preservative for 24 hours, 48 hours, 14 days and 15 days respectively. Here also the changes occurred between the raw and the cooked values. Cooking methods 


\section{International Journal of Science and Research (IJSR) \\ ISSN (Online): 2319-7064 \\ Index Copernicus Value (2013): 6.14 | Impact Factor (2014): 5.611}

significantly differed from the raw values. It also indicated that the highest loss was in boiling method whereas the lowest was in deep frying; rather the protein content was increased in this method after preservation for 14 and 15 days.

Table 3 showed the difference of the protein contents of the fish preserved with the combination of salt and turmeric in terms of raw and cooked value. Data showed that significant difference was present between both the values. Here also the loss occurred in the boiling method as compared to other cooking methods.

Table 4 exhibited the comparison of the protein contents of the fish preserved with and without preservative for short and long time durations. Data showed that the significant difference was present among the protein contents in terms of raw and cooked values.

Table 5 exhibited the percentage of protein losses post cooking of the preserved fish without preservative in respect of raw for each preservation day. Most of the loss occurred in boiling and the nutrient restoration occurred in deep frying.

Table 6 exhibited the percentage of protein losses following cooking of the preserved fish with the combination of salt and turmeric in respect of raw for each preservation day. Boiling causes the significant loss while deep frying causes protein restoration.

Table 7 exhibited the percentage of protein deterioration after cooking of the preserved fish without preservative in respect of fresh fish for each preservation day. Data indicated that protein loss occurred mostly in 48 hours.

Table 8 showed the percentage of protein reduction post cooking of the preserved fish with salt and turmeric in respect of fresh for each preservation day. Data indicated that loss of protein occurred gradually day by day preservation and the highest loss was found in the $15^{\text {th }}$ day of preservation.

Fig. a showed the comparison of the loss percentage of protein contents post cooking of the fish preserved with and without preservative. It was found that losses were more in boiling whereas less in deep frying.

Fig. b showed the loss percentage in preserved fish without preservative and the line trend indicated the highest loss in 48 hours

Fig. c exhibited the percentage of losses in fish preserved upto 15 days by using preservative. The line indicated that there was gradual loss but maximum loss occurred in $15^{\text {th }}$ day of preservation.

\section{Conclusion}

All cooking methods can reduce the protein content of the fish. The maximum restoration was found to be mostly in deep frying method while the loss occurred in boiling method. After preservation of this fish up to $15^{\text {th }}$ day, the deterioration of protein occurred in 48 hours but this deterioration can be reduced to some extent with the use of natural preservative that is combination of salt and turmeric, which help to restore protein content up to $15^{\text {th }}$ day of preservation. After considering all advantages and disadvantages, it can be said that deep frying is the best method for protein restoration among the other cooking methods and use of salt and turmeric can delay this deterioration post cooking.

\section{Acknowledgement}

The University Grants Commission (UGC) is thanked for awarding a Junior Research Fellowship to Uttiya Jana.

\section{References}

[1] Goldman, K. J. (1997). Regulation of body temperature in the white shark, Carcharodon carcharias. Journal of Comparative Physiology B, 167(6), 423-429.

[2] Erkan, N., Özden, Ö., \& Selçuk, A. (2010). Effect of frying, grilling, and steaming on amino acid composition of marine fishes. Journal of medicinal food, 13(6), 1524-1531.

[3] Mkandawire, K. T., \& Masamba, K. G. (2014). Effect of lemon juice treatment and sun drying on vitamin $C$ retention in three steam and water blanched indigenous vegetables over six weeks storage period. African Journal of Food Science, 8(6), 316-321.

[4] Yuan, G. F., Sun, B., Yuan, J., \& Wang, Q. M. (2009). Effects of different cooking methods on health-promoting compounds of broccoli. Journal of Zhejiang University Science B, 10(8), 580-588.

[5] Marimuthu, K., Thilaga, M., Kathiresan, S., Xavier, R., \& Mas, R. H. M. H. (2012). Effect of different cooking methods on proximate and mineral composition of striped snakehead fish (Channa striatus, Bloch). Journal of food science and technology, 49(3), 373-377.

[6] T. Akter 1 , A. T. A. Ahmed 1 , M. A. khaleque and M. Begum (2013), Effect of drying on quality of tengra (Mystus vittatus) treated with turmeric and salt. Unique Research Journal of Biological Science,1(1),001-005.

[7] Lowry, O. H., Rosebrough, N. J., Farr, A. L., \& Randall, R. J. (1951). Protein measurement with the Folin phenol reagent. J Biol Chem, 193(1), 265-275. 